\title{
OBSERVATIONS ON SOME PENNSYLVANIA COMMUNITY PROPERTY PROBLEMS
}

\author{
By Cuthbert H. Latta † and Kennethi W. Gemmill +
}

\section{INTRODUCTION}

On July 7, 1947, the Governor of Pennsylvania signed Senate Bill No. $615^{1}$ and thereupon Pennsylvania became the thirteenth community property state. ${ }^{2}$ As the origin of the community property system is known in a general way to all lawyers and has frequently been told, ${ }^{3}$ it will not be discussed here. So far as the origin of the Pennsylvania statute is concerned, a comparison of it with the Oklahoma Community Property Act of $1945^{4}$ leaves little room for doubt that the former is "based upon" the latter. The Pennsylvania Act consists of sixteen sections. Nine of these were copied verbatim from the Oklahoma Act, ${ }^{5}$ while six were copied with minor changes in phraseology required by differences in local terminology and practice. ${ }^{8}$ The remaining section, being the repealer, necessarily differs somewhat from its counterpart in the Oklahoma statute. ${ }^{7}$ In the face of this, it is hard to believe that the Pennsylvania legislature did much more than read and adopt the Oklahoma statute. It remains to be seen whether a virtually untested statute, such as that of Oklahoma, ${ }^{8}$ makes a good model. But this much is clear: that the Oklahoma statute, when placed on top of the statutory and common law of Pennsylvania, creates problems. The purpose of this article is to discuss a few of them.

$\dagger$ A. B., 1924, Princeton University; LL. B., 1928, University of Pittsburgh; Member of the Philadelphia Bar.

$\$$ A. B., 1932, Princeton University; LL. B., 1935, University of Pennsylvania; Author, Accruals to Date of Death for Income Tax Purposes, 90 U. PA. L. REv. 702 (1942); Member of the Philadelphia and New York Bars.

1. Act of July 7, 1947, No. 550; effective September 1, 1947.

2. The other states are Arizona, California, Idaho, Louisiana, Michigan, Nebraska, Nevada, New Mexico, Oklahoma, Oregon, Texas, and Washington.

3. de Funiak, Principles of Comminnity Property c. I, II (1943); McKay, Community Property c. $1-3$ (2d ed. 1925).

4. Okla. Stat. Ann. tit. 32, \$\$66-82 (Supp. 1946).

5. Sections $1,2,3,6,7,8,9,10$, and 13 of the Pennsylvania Act are the same as the sections numbered correspondingly in the Oklahoma Act.

6. E. g., in sections 5 and 15 of the Pennsylvania Act the word "real estate" was substituted for the word "homestead" in the corresponding sections of the Oklahoma Act. Despite the fact that the term homestead makes no sense in Pennsylvania law, it appeared in the bill as introduced in the Pennsylvania Senate. The nonsense was emended from Section 5 on third reading in the Senate; but in Section 15 it apparently went unnoticed until after final passage in the Senate and second reading in the House.

7. Section 16 of the Pennsylvania Act contains a blanket repealer of prior inconsistent laws, whereas section 16 of the Oklahoma Act reads : "Sections 51 to 65 inc., Tit. 32, Oklahoma Statutes 1941, are hereby repealed."

8. Apparently there are no reported cases involving the Oklahoma Act. 
The motives that prompted the Pennsylvania legislature to adopt the community property system are slightly less ideological than those that are said to have led the Visigoths to devise it. ${ }^{9}$ It is no secret that the purpose of the Pennsylvania Act is simply to afford relief from high federal income taxes. ${ }^{10}$ The way in which the community property system provides tax relief is quite simple. Under the system the income of a husband and his wife is divisible between them in halves; each then reports one-half of the total income in a separate return and pays tax on it; and a saving results from the fact that, with a graduated scale of tax rates, two people each having say $\$ 5,000$ of income pay less tax than one person with $\$ 10,000$. $^{11}$

In general the maximum tax saving results only when all of the taxable income of both husband and wife is split evenly. If some, but not all, of their taxable income is split, the maximum tax saving will not be achieved; indeed, in some cases a partial splitting will increase taxes. ${ }^{12}$ We mention this because it has an important bearing on the interpretation of certain provisions of the Pennsylvania Act. It is a familiar rule of statutory construction that doubtful words of an act should be interpreted so that the act will hit the mark at which it is aimed. ${ }^{13}$ Here the Act is aimed at reducing federal income taxes. The degree of its success will depend upon the degree to which it

9. DE Funiak, Principles of Community Property $\$ \$ 10,11$ (1943).

10. In approving Senate Bill No. 615 Governor Duff issued a statement reading in part as follows (History of Senate Bills, Session of 1947, p. 122) :

"The purpose of the recent legislation is primarily to effect savings on Federal Income Tax. I have been advised that the minimum savings to taxpayers of Pennsylvania under this bill will be $\$ 100,000,000$ a year. This is a consideration that cannot possibly be overlooked.

"I am not unaware that such a radical change in the law of Pennsylvania will cause some confusion and will be the cause of considerable litigation; but the fact that $\$ 100,000,000$ will be saved to the taxpayers of the Commonwealth is such a vast amount of money, particularly at a time the taxes are generally so onerous, that I believe that it is in the interest of the people of the Commonwealth to approve the bill and run the risk of the confusion that will be caused by the new legislation."

11. At current tax rates, splitting an income in half will produce a tax saving of $\$ 38$ on a net income (before exemptions) of $\$ 5,000$, a saving of $\$ 342$ on a net income of $\$ 10,000$, a saving of $\$ 893$ on a net income of $\$ 15,000$, and a saving of $\$ 1,700$ on a net income of $\$ 20,000$.

12. For example, if the husband has a $\$ 10,000$ salary-which is clearly community property-and the wife has $\$ 20,000$ of income from investments, there will be a tax saving only if the wife's investment income is treated as community property. If that is done, the total family income of $\$ 30,000$ will be split in half, each will pay a tax of $\$ 4,270$ on $\$ 15,000$, the total of the two taxes will be $\$ 8,540$, and this will be $\$ 451$ less than if the husband had paid tax on his $\$ 10,000$ salary and the wife had paid tax on her $\$ 20,000$ of investment income. On the other hand, if the husband's salary is treated as community property but the wife's investment income is treated as separate property, then only the salary will be split, the husband will pay a tax of $\$ 921$ on $\$ 5,000$, the wife will pay a tax of $\$ 9,363$ on $\$ 25,000$ (i. e., all of her investment income plus one-half of her husband's salary), and the total of the two taxes will be $\$ 1,292$ greater than under the regime of separate property.

13. Pennsylvania Statutory Construction Act of May 28, 1937, P. L. 1019, art. IV, $\S 51$, PA. STAT. ANN. tit. 46, $\$ 551$ (Purdon, 1938); Commonwealth v. Chalfant, 352 Pa. 193, 42 A. 2d 587 (1945); Swartley v. Harris, 351 Pa. 116, 40 A. $2 d 409$ (1945). 
divides the taxable income of husbands and wives. Therefore, in cases where it is doubtful whether items of income should be treated as community property or as separate property, the doubt should be resolved in favor of treating them as belonging to the community.

The specifications for a community property system that will produce income tax savings were laid down by the United States Supreme Court in Poe v. Seaborn ${ }^{14}$ and Commissioner v. Harmon. ${ }^{15}$ After the passage of the Pennsylvania Act the Commissioner of Internal Revenue, in reply to a request of the Bank and Trust Company Tax Association of Philadelphia, ruled that the Act meets the specifications. ${ }^{16}$ Thus the Act has taken its first step successfully.

II

\section{Income From Separate Property}

\section{A. In General}

The first question to be considered is whether income from separate property is separate or community. The question arises because the Pennsylvania Act fails to cover the point specifically; and it is worth considering in some detail not only because it is important in itself but also because it bears on the question whether trust income is separate or community. ${ }^{17}$

The pertinent provisions of the Pennsylvania Act are in the first four sections. Section 1 provides:

"All property of the husband, both real and personal, owned or claimed by him before marriage or before the effective date of this act, whichever is later, and that acquired afterwards by gift, devise, or descent or received as compensation for personal injuries, shall be his separate property."

Section 2 defines the wife's separate property in the same way. Section 3 provides that all property acquired by either the husband or the wife during the existence of the community, "except that which is the separate property of either as hereinabove defined," shall be com-

14. 282 U. S. 101 (1930).

15. 323 U. S. 44 (1944).

16. The ruling dated August 27, 1947, reads in part:

"Upon examination of the provisions of the Pennsylvania Community Property Act, approved July 7, 1947, and effective September 1, 1947 (Pa. Senate Bill No. 615, 1947 Session), it is the opinion of this office that said Act establishes a community property system which, for Federal income tax purposes, satisfies the test prescribed by the Supreme Court of the United States in Poe v. Seaborn, 282 U. S. 101, Ct. D. 259, C. B. IX-2, 202 (1930) and Commissioner v. Harmon (323 U. S. 44, Ct. D. 1616, C. B. 1944, 166).

"In view of the foregoing, it is held that a husband and wife who are domiciled in the State of Pennsylvania are entitled to include in their separate Federal income tax returns one-half of their community income received and accrued on and after September 1, 1947, the effective date of the Pennsylvania Community Property Act."

17. Infra pp. 26-29. 
munity property. Since income from separate property is not specifically mentioned in the definitions of separate property contained in Sections 1 and 2, on the surface it would appear to fall within the catch-all definition of community property contained in Section 3. Implied confirmation of this is supplied by Section 4: it says that the "wife shall have the management and control and may dispose of . . . that portion of the common or 'community property consisting of . . . all rents, interest, dividends, and other income from her separate property." However, despite this implication some lawyers doubt whether income from separate property belongs to the community, and the Commissioner of Internal Revenue has gone so far as to rule that it does not. ${ }^{18}$ Probably the chief cause of the doubt is that the Supreme Court of California disagrees with the Supreme Court of Texas on the interpretation of substantially the same words as are used in the definitions of separate property contained in Sections 1 and 2 of the Pennsylvania Act. In George v. Ransom ${ }^{19}$ the California court held that the words require that income from separate property be treated as separate property, whereas in Arnold v. Leonard ${ }^{20}$ the Texas court held that the words require no such thing and that income from separate property belongs to the community. The decisions are irreconcilable, and therefore the only course is to look elsewhere for clues to the meaning of the Pennsylvania Act.

A survey of the community property statutes in force when the Pennsylvania Act was pending in the legislature indicates quite clearly that the framers of the Act must have expected, as Section 4 implies, that income from separate property would be community property. At that time there were nine community property states. In seven of them the question whether income from separate property is separate or community was expressly covered by statute. ${ }^{21}$ California was one

18. As to the lawyer's doubt see Finucrary Revrew (Girard Trust Co., Philadelphia), Aug. 1947, pp. 3-4. The ruling is dated September 4, 1947, and reads in part:

"Under the Pennsylvania Community Property Act (sections 1 and 2) the separately owned property, both real and personal, owned or claimed by either spouse before marriage or before the effective date of the Act, whichever is later, and that acquired afterwards by gift, devise, or descent or received as compensation for personal injuries, remains the separate property of the respective spouse. Thus, for Federal income tax purposes, the income received after September 1, 1947, from separate investments of the spouses is the separate income of and is taxable to the spouse who owns the investments."

19. 15 Cal. 322 (1860) ; accord, Boyd v. Oser, 23 Cal. 2d 613, 620, 145 P. 2d 312, 316 (1944).

20. 114 Tex. 535, 273 S. W. 799 (1925) ; followed, Frame v. Frame, 120 Tex. 61, 36 S. W. 2d 152 (1931).

21. Income from separate property expressly made separate property: ARIz. CoDE $\$ \$ 63-302$ (1939); CaL. Civ. Code $\$ \$ 162-3$ (1941) ; NEv. Comp. I Aws $\$ 3355$ (1929); N. M. AnN. ST. $\$ \S 68-302,303$ (1929); WasH. Rev. STAT. \$6891-2 (Remington, 1932). Income from separate property expressly made community property: IDAHo CODE ANN. \$31-907 (1932). Subject to qualifications, income from separate property expressly made community property : LA. Crv. CoDE art. 2386 (1932). 
of the seven: its code provided, as it still does, that "the rents, issues, and profits" of separate property shall be separate property. ${ }^{22}$ The only two states whose statutes were silent on the point were Oklahoma and Texas. ${ }^{23}$ Apparently the rule in Oklahoma is the same as that in Texas, $i$. e. that income from separate property belongs to the community. ${ }^{24}$ In view of this background, it seems clear that the Pennsylvania legislature, when it aligned itself with Oklahoma and Texas by omitting a specific reference to income from separate property, must have intended to adopt the rule prevailing in those states. Surely if it had intended to adopt California's rule, it would have followed California's example by specifically stating that "the rents, issues, and profits" of separate property shall be separate property. ${ }^{25}$

If, despite the historical background of the Act and the implication of Section 4, it is regarded as doubtful whether income from separate property is community property, then the doubt should be resolved in favor of treating it as community property simply because that treatment will result in the greatest amount of income tax relief. ${ }^{26}$ Unless this is done, many Pennsylvania couples will get no relief under the Act and some will have their taxes increased as a result of it. ${ }^{27}$

It has been suggested that the Act should be interpreted as treating income from separate property as separate property in order to avoid constitutional doubts. ${ }^{28}$ The objection to this is that it would result in an unnecessary loss of income tax relief in cases not affected by the constitutional doubts. ${ }^{29}$ If these doubts must be reckoned with, it would seem that a better way of avoiding them is to construe the Act so that income from separate property will be community property and to restrict the Act's application to cases where the separate property is acquired after the effective date of the Act or where the marriage occurs after that date. ${ }^{30}$ This could be done under the well-settled rule that the application of a statute may be restricted to part of the field it was intended to cover if it would be unconstitutional as applied to the balance. ${ }^{31}$

22. Cal. Crv. CoDe $\$ \$ 162-3$ (1941).

23. OkLa. Stat. tit. 32, \$§ 66-67; Tex. Rev. Crv. Stat. arts. 4613-4 (1936).

24. Cf. Harmon v. Oklahoma, 189 Okla. 475, 118 P. 2d 205 (1941). (1946).

25. Cf. Commonwealth v. One Cadillac, 158 Pa. Super. 392, 397, 45 A. $2 d 406$

26. Supra note 13 and discussion pertaining thereto.

27. Supra note 12 and discussion pertaining thereto.

28. Finucrary Revrew (Girard Trust Co., Philadelphia), Aug. 1947, pp. 3-4.

29. Supra note 12.

30. This construction will require an apportionment of income between capital existing at the start of the community and personal service in partnerships and individual proprietorships. See note 89 infra.

31. Dahnke-Waiter Co. v. Bondurant, 257 U. S. 282, 289 (1921) ; Kansas City Ry. Co. v. Anderson, 233 U. S. 325, 329-30 (1914) ; Poindexter v. Greenhow, 114 U. S. 270, 295 (1884) ; Greenough v. Greenough, 11 Pa. 489 (1849); Cornell v. Beaver County, 3 Pa. Dist. 783 (C. P. Beaver Co. 1894); 1 Cooley, Constitutional Lmmitatrons 
Accordingly, it would seem that the Act can and should be interpreted as establishing for Pennsylvania the same rule that was laid down for Texas in Arnold $v$. Leonard ${ }^{32}$-that income from separate property belongs to the community.

\section{B. Meaning of Income}

Before leaving this subject, it may be well to refer to the question of how receipts from separate property should be allocated to principal (separate property) and income (community property). It has been suggested ${ }^{33}$ that Pennsylvania's new Principal and Income Act ${ }^{34}$ may govern the question by analogy. It would appear, however, that resort to that Act may lead to trouble.

For example, suppose that after September 1, 1947, a wife receives shares of corporate stock by gift and that a short time later, before any earnings are accumulated and before any change in the intrinsic value of the stock, the corporation declares a dividend payable in shares of its own stock of a different rank. It is clear that the original shares, having been acquired by the wife through a gift, are her separate property. If the usual rule of community property law is applied, the declaration of the dividend would be regarded as merely changing the form of the separate property and the new shares received would remain separate property. ${ }^{35}$ If, on the other hand, the Principal and Income Act is applied by analogy, then under Section 5 (1) the dividend would be regarded as income; and since income from separate property belongs to the community, the dividend would be allocated to the community.

Similar difficulties will arise if receipts from natural resources are allocated by analogy to the Principal and Income Act. Thus, suppose that after September 1, 1947, a wife receives land by gift and

366-7 (8th ed. 1927). This is not the type of problem that can be solved by the doctrine of severability: there is no part of the definition sections that can be discarded without interfering with the Act's prospective application. Cf. Baldwin v. Franks, 120 U. S. 678, 685-6 (1887).

32. 114 Tex. 535, 273 S. W. 799 (1925).

33. Philadelphia Legal Intelligencer, p. 221, col. 4, Aug. 28, 1947.

34. Act of July 3, 1947, No. 516, effective July 3, 1947. The point being discussed is obviously outside the scope of the Act, which is defined by Section 2 as "the ascertainment of income and principal, and the apportionment of receipts and expenses between tenants and remaindermen, in all cases where a principal has been established."

35. E. g., Scofield v. Weiss, 131 F. 2d 631 (C. C. A. 5th 1942); 1 DE FunIaK, Principles of Cummunity Property, $\$ 77$, p. 205 . Section 4 of the Pennsylvania Community Property Act lends itself to the argument that all stock dividends are community, since the section implies that "all rents, interest, dividends, and other income" from the wife's separate property belong to the community; but the argument could hardly be regarded as sound. Cf. Boyer's Appeal, $224 \mathrm{~Pa}$. 144, 153, 73 Atl. 320, 323 (1909); holding that "the settlor meant to indicate by the use of the three words, 'dividends,' 'income,' and 'profits' . . . everything in the way of advantage or benefit which might accrue from the stock, without decreasing the original value of the capital which it represented"; accord, Bard's Estate, 339 Pa. 433, 437-8, 13 A. 2d 711, 713 (1940). 
then enters into a coal lease by which she sells the coal for a royalty on each ton of coal as removed. In effect this is simply a sale of part of the wife's separate property. ${ }^{36}$ Under community property principles, the proceeds of the sale (i.e. the royalties) would be principal and therefore separate property. ${ }^{37}$ But under Section 9 of the Principal and Income Act only two-thirds would be treated as principal and hence separate property; the remaining one-third would be treated as income and hence community property.

It may be doubted whether fundamental rules of community property law may be thus upset by analogy based on a statute designed to cover an entirely different subject, particularly when the result may be to dissipate separate property. The better course would be to say that only those items that fall within the common law definition of income may be treated as income from separate property and therefore allocable to the community.

\section{III}

\section{Trust IN COME}

\section{A. In General}

To take the problem in a simple form, suppose that after September 1, 1947, a Pennsylvania resident dies leaving a will by which he places his estate in trust to pay the income to his married daughter, also a Pennsylvania resident, until her death, and then to pay the principal to others. Will the income, when paid to the daughter, be her separate property or will it belong to the community? The answer depends on whether the income falls within the definition of separate property contained in Section 2 of the Pennsylvania Act; if it does not, then under Section 3 it is community property. It will be recalled that Section 2 divides the wife's separate property into three classes: (1) property owned or claimed by the wife before marriage or before September 1, 1947, (2) property "acquired afterwards by gift, devise or descent," and (3) property received as compensation for personal injuries. $^{38}$ By definition the daughter's income falls outside the first and third classes. What about the second? Probably the most natural first reaction is to say that the daughter's income is acquired by gift and hence is her separate property. However, the available cases point the other way.

36. E. g., Marshall v. Mellon, 179 Pa. 371, 375, 36 At1. 201 (1897).

37. Commissioner of Internal Revenue v. Gray, 159 F. 2d 834, 842 (C. C. A. 5th 1947) ; Commissioner of Internal Revenue v. Wilson, 76 F. 2 d 766, 770 (C. C. A. 5th 1935) S State v. Hatcher, 115 Tex. 332, 281 S. W. 192 (1926); Stephens v. Stephens, 292 S. W. 290 (Tex. 1927).

38. Supra p. 22. 
Apparently most, if not all, of the reported cases dealing directly with the problem originated in Texas; and all but a few are tax cases that ended in the Circuit Court of Appeals for the Fifth Circuit. The first of these is Commissioner $v$. Terry. ${ }^{39}$ There it was held that income received by a Texas wife as life beneficiary of a trust under a New York will was community property and therefore divisible and taxable to the wife and her husband by halves. This result was reached by blending the Texas Supreme Court's decision in Arnold v. Leonard $^{40}$ with the United States Supreme Court's decision in Irzoin $v$. Gavit. ${ }^{41}$ It will be recalled that Arnold $v$. Leonard establishes the rule that in Texas income from separate property belongs to the community. Irwin v. Gavit, on the other hand, stands for the principle that a life beneficiary of a trust is the equitable owner of the trust res. ${ }^{42}$ The result of the synthesis is this:

1. When an equitable life estate is created by gift, the beneficiary becomes the equitable owner of the trust res;

2. Since by the gift the beneficiary acquires the trust res and since property thus acquired is separate, it follows that the trust res is the beneficiary's separate property;

3. Since the income distributed to the beneficiary comes from the trust res, which is the beneficiary's separate property, and since under Arnold v. Leonard income from separate property belongs to the community, it follows that trust income is community property.

This is the line of reasoning that underlies Commissioner v. Terry and a series of cases that followed it. ${ }^{43}$

It would appear that the Circuit Court of Appeals for the Fifth Circuit correctly appraised the result of blending Arnold v. Leonard

39. 69 F. 2 d 969 (C. C. A. 5th 1934).

40. 114 Tex. 535, 273 S. W. 799 (1925).

41. 268 U. S. 161 (1925).

42. This is not the primary ground on which Irwin v. Gavit rests. The taxpayer's argument was that the statute defined taxable income as including "gains or profits and income derived from any source whatever, including the income from but not the value of property acquired by gift, bequest, devise or descent," and therefore that the trust income, having been acquired by bequest, was exempt from tax. The primary ground on which the case was decided is that even if the income-was acquired by bequest, still it did not come within the exemption because the exemption was intended to apply only to gifts of principal and not to gifts of income. Id. at 167. However, the court (Holmes, J.) pointed out, as an alternative ground for the decision, that in fact the income was not acquired by gift: where an equitable life estate is created, what the beneficiary acquires is, not the income, but rather the equitable ownership of the trust res. (Id. at 167-8.)

43. Commissioner v. Wilson, 76 F. $2 d 766$ (C. C. A. 5th 1935) ; Commissioner v. Porter, 148 F. 2d 566 (C. C. A. 5th 1945); Commissioner v. Snowden, 148 F. 2d 569 (C. C. A. 5th 1945); McFaddin v. Commissioner, 148 F. 2d 570 (C. C. A. 5th 1945); Commissioner v. Sims, 148 F. 2d 574 (C. C. A. 5th 1945); Eva Lavino Griffiths, 30 B. T. A. 852 (1934); accord, Ernestine Mitchell, 38 B. T. A. 1336 (1938). 
with Irwin v. Gavit. Therefore, if the ingredients of the blend are part of the law of Pennsylvania, on principle the line of cases headed by Commissioner v. Terry should be followed in Pennsylvania. For reasons stated above, the rule of Arnold $v$. Leonard ought to be applied in Pennsylvania. ${ }^{44}$ So far as the concept underlying Irzerin $v$. Gavit is concerned, there can be no doubt that it is the law of Pennslyvania. In Commonwealth v. Stewart, ${ }^{45}$ the Supreme Court of Pennsylvania held:

"... the modern trend of equity jurisprudence has inclined toward the doctrine that, in addition to rights against the trustee, the beneficiary also has rights in rem, an actual property interest in the subject-matter of the trust, an equitable ownership of the trust res.

“. . . In Irwin v. Gavit, 268 U. S. 161, 167, the court said: "The courts below went on the ground that the gift to the plaintiff was a bequest and carried no interest in the corpus of the fund. We do not regard those considerations as conclusive, . . . but if it were material a gift of the income of a fund ordinarily is treated by equity as creating an interest in the fund. Apart from technicalities we can perceive no distinction relevant to the question before us between a gift of the fund for life and a gift of the income from it. The fund is appropriated to the production of the same result whichever form the gift takes. ...'

"Without undertaking to collate authorities from state jurisdictions, we have in our own state some indication that Pennsylvania is in accord with these views. . . .

"The fact that appellee [the beneficiary] has only a right to the income from the trust for life, and not a greater interest, as, for example, an estate in remainder or a power of appointment of the corpus, obviously goes merely to the quantum of her equitable estate in the trust res and not to the existence of such an estate." 46

Accordingly, it is likely that the rule of Commissioner $v$. Terry-that trust income belongs to the community-will be the Pennsylvania rule.

Apparently the only reported decision of a Texas court on the subject is McClelland $v$. McClelland. ${ }^{47}$ There a husband domiciled in Texas had a life estate in a trust under his father's will. The will gave him $\$ 150$ a month for his support and maintenance and authorized the executors to make such advances, in addition to the monthly sums, out of the estate as they might think proper. The husband and wife were divorced and thus it became necessary to divide their community

44. Supra pp. 23-25.

45. $338 \mathrm{~Pa} .9,12 \mathrm{~A} .2 \mathrm{~d} 444$ (1940).

46. Id. at 14-15, $12 \mathrm{~A}$. $2 \mathrm{~d}$ at 447 . To the same effect see Jones v. Jones, $344 \mathrm{~Pa}$. 310, 25 A. 2d 327 (1942). Compare Scott, The Nature of the Rights of the Cestui Que Trust, 17 CoL. L. REv. 269 (1917), with Stone, The Nature of the Rights of the Cestui Que Trust, 17 CoL. L. Rev. 467 (1917).

47. 37 S. W. 350 (Tex. Civ. App. 1896). 
property. At the time there was a substantial amount of income accumulated in the hands of the executors, and the wife claimed that this was payable to the husband and was community property. The court held that under the will the husband could not force the trustees to advance the accumulations to him, that his wife's rights were no greater than his, and therefore that the accumulations did not belong either to the husband or to the community. In addition the wife claimed that the income actually distributed to the husband was community property and should be accounted for as such. The court also rejected this contention, and in so doing said:

"In this connection we will take occasion to say that the wife is not entitled to any interest in the amounts received by the appellant $\mathrm{McClelland}$ [the husband] from the executors, because these amounts were his separate property, devised to him by the will, in which the wife had no community interest." 48

This appears to be a clear holding that trust income is property acquired by gift or devise and hence does not belong to the community. In Commissioner $v$. Porter, ${ }^{49}$ an effort was made to distinguish this case on the basis that it "dealt not with income which had been paid over to the beneficiary but with a claim to income still held in the trust," ${ }^{50}$ but this distinction is not supported by the facts of the case. ${ }^{51}$ Perhaps the case could be distinguished on the ground that under the will the monthly payments to the husband were earmarked for his support and maintenance and hence the trust was a separate use trust. ${ }^{52}$ In any event, the case conflicts with the concept that the beneficiary of a trust is the equitable owner of the trust res and hence the res, and not the income from it, is the property that he acquires by gift; and since this concept has already been adopted in Pennsylvania, it would seem that the McClelland case should not be followed.

It might be suggested that constitutional difficulties will arise if the Pennsylvania Act is interpreted as treating trust income as community property and that these difficulties should be avoided by interpreting it so that trust income will be separate property. For reasons explained above, ${ }^{53}$ the better way of avoiding the possible difficulties would be to interpret the Act as treating trust income as community property and to restrict its application to cases where the trust is created or the marriage occurs after September 1, 1947. This method

48. $I d$. at 359 .

49. 148 F. 2 d 566 (C. C. A. 5th 1945).

50. $I d$. at 568 .

51. 37 S. W. at 357.

52. Infra p. 30.

53. Supra p. 24. 
will avoid the constitutional difficulties just as effectively as the other and will afford greater tax savings.

\section{B. Spendthrift Trusts}

A word about spendthrift trusts may be appropriate. In Commissioner $v$. Porter ${ }^{54}$ it was held that income received by Texas beneficiaries from a spendthrift trust is community property. The theory of this is that "as long as the income was in the hands of the trustees and undistributed it was protected, but as soon as it was paid over it passed to the daughters [the beneficiaries] as their property, freely and completely alienable, and as fully subject as any other unrestricted property of theirs to the ordinary impact of the law." ${ }^{55}$ This appears to be entirely sound. ${ }^{\text {sb }}$

\section{Separate Use Trust}

Another type of trust that should not be overlooked is the separate use trust. In Hutchinson v. Mitchell ${ }^{57}$ it was decided that the law of Texas permits a separate use trust for a married woman and that "the separate equitable estate of the wife is fully recognized and the rules of the common law apply to it," 58 with the result that the trust income does not belong to the community. This case has been criticized "as a decision of the Semicolon or Carpet Bag Court of Texas and therefore not authoritative." 59 However, substantially the same result was reached in Sullivan $v$. Skinner, ${ }^{60}$ which involved a legal rather than equitable life estate. In Commissioner $v$. Porter, ${ }^{61}$ the court referred to the question but refrained from passing upon it, since the trust instrument there involved did not express an intent to create a separate use trust. In view of the fact that the law of Pennsylvania, like the law of Texas, allows wide latitude in the imposition of conditions on gifts, it is reasonable to suppose that the Pennsylvania courts would hold that income from a separate use trust does not belong to the community. Accordingly, in any case where a settlor or testator wishes to make certain that the beneficiary's spouse will not have any interest, a separate use trust should be considered. ${ }^{62}$

54. 148 F. 2 d 566 (C. C. A. 5th 1945).

55. Id. at 568 .

56. Cf. Griswold, Spendthrift Trusts $\$ 370$ (2d ed. 1947); Provident Trust Co. v. Gordon, $41 \mathrm{~Pa}$. D. \& C. 188 (1941).

57. 39 Tex. 487 (1873).

58. Id. at 493 .

59. Commissioner v. Porter, 148 F. $2 d$ 566, 568 (C. C. A. 5th 1945).

60. 66 S. W. 680 (Tex. Civ. App. 1902).

61. 148 F. 2 d 566 (C. C. A. 5th 1945).

62. It should be borne in mind that in Pennsylvania "a separate use can only be created for the benefit of a woman actually married, or in immediate contemplation of marriage; and although effectual as respects the first marriage, it will not revive for her protection under a second marriage": Quin's Estate, 144 Pa. 444, 453, 22 At1. 


\section{IV}

\section{Capital Gains on Sale of Separate Property}

\section{A. In General}

The next problem to be considered can best be explained by illustration. Suppose that a man buys stock in a company by which he is not employed, that he pays $\$ 1,000$ for it, that later he marries at a time when it is worth $\$ 1,200$, and that while still married he sells it for $\$ 1,500$. Since the husband was not employed by the company, it is obvious that community effort did not contribute to the $\$ 500$ gain realized on the sale of the stock. Does any part of the gain belong to the community, or is all of it the husband's separate property?

The Pennsylvania Community Property Act contains no reference whatever to increases in the value of property. Section 3, however, does mention gains: it provides that "all the effects which the husband and wife possess at the time the marriage may be dissolved shall be regarded as common effects or gains unless the contrary be satisfactorily proved". This reference to gains is of no real help in solving the problem under consideration; for it will be noticed that the Act does not say that "gains" shall be community property but rather that "effects" shall be regarded as common effects or gains. There is nothing to indicate that the word "effects" was intended to refer to "gains", and consequently a statement that effects shall be treated as community property throws no light on the question whether gains should be treated as community property. Since the Act throws no light on this problem, the rule applied in other states will be examined to aid in its solution.

\section{B. The Authorities}

A typical statement of the general rule is that "capital gains from the sale of separate property are everywhere separate property." ${ }^{83}$ The California courts held in $M c D u f f v . M c D u f f{ }^{64}$ that capital increase from separate property was separate property without reference to the California statute, ${ }^{65}$ which provides that the rents, issues and profits of separate property are separate property. The question in that case was whether the gain realized upon the sale of the farm which the husband had purchased before marriage was separate property or com-

965, 966 (1891). Also, it has been held that in Pennsylvania a separate use trust for a male is impossible; Klock v. Mangin, 43 Montg. Co. L. Rep. 248 (C. P. Montg. Co. 1927) ; see Bouvier's Estate, 12 Pa. Dist. 149 (O. C. Phila. 1903). However, now that a separate use trust for a male would have some point, perhaps the rule will be changed.

63. 20 TEx. L. REv. 542 (1942).

64. 48 Cal. App. 175, 191 Pac. 957 (1920).

65. Cal. Civ. Code $\$ \$ 162-163$ (Deering, 1941). 
munity property. In holding that the increase in the farm value was not community property the court said: ${ }^{66}$

". . . it is obvious that the increase in the value of the farm from the time of the purchase in 1881 to the time of the sale in 1913 was due alone to the natural enhancement of real estate values, and not to any improvements made thereon through the activity, ability, or capacity of plaintiff or defendant."

In Louisiana the statute ${ }^{67}$ provides that the other spouse is not entitled to any part of the increase in separate property "if it be proved that the increase is due only to the ordinary course of things, to the rise in the value of property, or to the chances of trade." ${ }^{88}$

The definition of separate property in the Texas statute ${ }^{69}$ provides that "the increase of all lands" which are separate property shall be separate property. The statute contains no provision with regard to the increase of personal property. The statute does, however, contain a presumption similar to that contained in Section 3 of the Pennsylvania statute.

The Texas court in Evans v. Purinton ${ }^{70}$ stated that the rule applicable to personal property is different from the rule applicable to land, as follows: ${ }^{71}$

"As applied to land, there is a different rule from that which obtains as to the profits arising from the purchase and repurchase, the sale and resale, of goods or personal property, of which the original stock was purchased with the separate means of the wife. By our law, the increase of all land the separate property of either of the spouses (unlike the increase of money or other personal property) remains the separate property of that spouse."

66. McDuff v. McDuff, 48 Cal. App. 175, 191 Pac. 957 (1920).

67. LA. CIV. CoDE, art. 2408 (Dart, 1945).

68. Beals v. Fontenot, 111 F. 2d 956 (C. C. A. 5th 1940), is an estate tax case where the appellant wife contended that the increase in value of stock which her husband owned prior to his marriage was community property. In denying her contention, the court wrote as follows at p. 959 :

"Appellant concedes as she must that in the usual case of corporate stock, no reward is due the community because in such cases, the increase of value is certainly due 'only in the ordinary course of things, to the rise in the value of property, or to the chances of trade.' She insists though, that by the stipulation in this case it is 'proved that the increase $* * *$ is the result of the common labor, expenses or industry' within the meaning of Civil Code, Article 2408. Appellee, on its part, insists that in the case of this stock as in the case of corporate stock in general, it must be found, as the district court did, that the increase in value of the stock is due to the efforts of the corporation, the ordinary course of things, the rise in the value of the property and chances of trade and that there is no reason here to disregard the corporate fiction.

"Nothing in the proof takes the case out of the general rule established by the code that property owned separately before marriage does not through the increase of value after marriage become either as to the original or the increased value, property of the community."

69. Tex. STAT. ANN. tit. 13, art. 4613, 4614 (Vernon, 1936).

70. 34 S. W. 350 (Tex. Civ. App. 1896).

71. Id. at 352 . 
The reason for the foregoing rule was stated to be that the statute had expressly covered the increase of land and slaves and thus it must be implied that the increase of other property becomes community property. ${ }^{72}$ The cases so stating, however, were cases involving the question as to whether calves derived from separate property and cotton grown on separate property were separate or community property. These cases may be distinguished on the ground that the calves and the cotton were income derived from separate property and thus community property.

The later Texas cases relating to the increases of personalty which is the separate property of one of the spouses do not discuss these early cases; those cases hold that such increases are separate property. An example is Stringfellow $v$. Sorrells. ${ }^{73}$ In that case the wife owned as her separate property two mules worth $\$ 35$ apiece at her marriage. Four years later each of the mules was worth $\$ 75$ and a creditor of her husband attached them. During the marriage the husband had managed and cared for the mules, and they were fed out of community property. The creditor argued that the enhanced value of the mules resulted from the husband's care and feeding of them and that this increase of the wife's separate estate was community property liable for his debts. In rendering judgment for the wife, the court wrote as follows : ${ }^{74}$

". . . there can be no 'increase' of the wife's separate estate if composed solely of specific mules at the time of her marriage . . . It would tend to entirely destroy the corpus of the wife's estate, consisting of live personal property, to declare that an augmentation in weight or value should be deemed an 'increase' of the property itself so as to constitute a part of the community to that extent."

In Oglesby $v$. Potts, ${ }^{75}$ the court, in discussing the investment of the proceeds of the wife's separate real and personal property, stated that it was well settled "that the value due to an appreciated market, natural growth, increased size, and the like, remains hers, and does not become part of the community as increase of her property."

Tax cases involving the question whether gain from a spouse's separate property is separate or community property have concluded that the Texas decisions make such a gain separate property. ${ }^{76}$

72. Howard v. York, 20 Tex. 670 (1858) ; DeBlane v. Hugh, Lynch \& Co., 23 Tex. 25 (1859).

73. 82 Tex. 277,18 S. W. 689 (1891).

74. Id. at $278-279,18 \mathrm{~S}$. W. at 689 .

75. 40 S. W. 2 d 815, 817 (Tex. Civ. App. 1931)

76. O'Connor v. Comm'r., 110 F. 2 d 652 (C. C. A. 5th 1940), where the profit from a sale of bonds which were the separate property of a husband domiciled in 
From the later Texas cases and the cases in the Federal courts it appears that the law of Texas now is to the effect that gain on separate property remains separate property and that the statements in the earlier Texas cases that gain on separate property becomes community property are not followed. The rule in Texas is particularly applicable to Pennsylvania because the Texas statute ${ }^{77}$ contains the same wording as Section 3 of the Pennsylvania statute that all property "acquired" during marriage is community property except that which is defined as separate property and that all of the effects which the husband and wife possess at the time the marriage may be dissolved shall be regarded as "common effects or gains," unless the contrary be satisfactorily proved. No Texas' cases have been found which discuss the effect of the word "gains" in the Section of the Texas statute quoted above. Since the Texas statute and the Pennsylvania statute are the same in this regard, it would seem that the law in Pennsylvania would be that the gains on the sale of separate property remain separate property, that is, in the example above, neither the $\$ 300$ nor the $\$ 500$ would be community property but the total $\$ 500$ would be separate property.

This conclusion does not overlook the fact that the Texas statute ${ }^{78}$ expressly provides that the increase of all lands shall be separate property, and the fact that the 1939 Oklahoma statute ${ }^{79}$ contained a similar provision which was omitted from Sections 1 and 2 of the 1945 Oklahoma statute. ${ }^{80}$ With regard to Texas, the more recent cases, in

Texas was held taxable to him; Comm'r. v. Skaggs, 122 F. 2 d 721, 722 (C. C. A. 5th 1941), cert. denied, 315 U. S. 811 (1942), where the court discusses the rule in Texas in the following language:

"In defining the separate property of husband and wife as that owned or claimed before marriage and that acquired afterwards by gift, devise or descent, the statutes add 'as also the increase of all lands thus acquired.' Vernon's Ann. Civ. St. arts. 4613, 4614. The Board following its decision in the case of W. T. Carter, Jr. v. Commissioner, $36 \mathrm{~B}$. T. A. 853, held the statutory meaning to be that while any increase in value of separate land realized by a sale would be separate property, it would be otherwise as to personal property, because the mention of increase of land excludes increase of personalty, and the statutes expressly make to be community property all acquisitions during marriage which are not separate property. The argument is plausible, but we do not think the construction is in accord with the Texas decisions. These recognize the identifiable proceeds of sale of separate property to be separate property, whether the property sold be real or personal. In O'Connor v. Commissioner, 5 Cir., $110 \mathrm{~F} .2 \mathrm{~d}^{\mathrm{P}} 652$, we held the gain on a sale of separate personal property to be taxable to the separate owner, and cited the Texas decisions from the beginning, affirming the Board's decision in that case. There are cases in Texas in which it was shown that the gain realized came largely from the expenditure of the time and efforts of the spouse during the marriage, in which the claims of the community were recognized, but in such instances the proceeds of the sale were not identified as arising wholly from the separate property. The Board's case of W. T. Carter, Jr., supra, was of that kind and was correctly distinguished on that ground in deciding the O'Connor case, supra, 40 B. T. A. 489 . We think the O'Connor case is controlling here."

77. Tex. STAT. ANN. tit. 13, art. 4619, 11 (Vernon, 1940).

78. Id. at art. 4613,4614 .

79. Oklahoma Community Property AcF, $\$ 53$ (1939).

80. OrLahoma Community PRoperty ACr, $\$ \$ 1,2$ (1945). 
reaching their conclusions, place no reliance upon the fact that the increase of lands is expressly covered in the statute. With regard to Oklahoma, at the time the 1945 Oklahoma statute was adopted it appears that the Texas rule was settled that the increase in separate property remained separate property. Hence, it can be argued that the provision with regard to the increase in lands previously contained in the Oklahoma statute was omitted because it was unnecessary. ${ }^{81}$

The discussion up to this point deals with gains caused by natural enhancement of property values, without any contribution of labor or industry by the husband or wife. Should a gain that is due at least partly to the labor or industry of the husband or wife be treated as separate or community property?

Carter v. Commissioner ${ }^{82}$ held that the gain on the sale of stock of a Texas corporation managed by the husband was capital gain to the community. The decision appears to be based on three propositions: (1) that since some of the shares of stock were acquired as separate property and some as community property and all were commingled so that it was impossible to identify any particular shares, it was presumed that the property was community property; (2) that the husband's work and efforts in managing the corporation had built up the increase in value and thus it should be treated as community property; and (3) that the law in Texas was to the effect that the gain from the sale of any separate property was community property. The third reason was said to be erroneous by the Fifth Circuit Court of Appeals in Commissioner v. Skaggs. ${ }^{83}$ The same Circuit Court, ${ }^{84}$ by concurring in the conclusion of the Board of Tax Appeals, has treated the Carter case as one where community and separate property were so commingled that the separate property could not be identified; thus it was presumed that all of the property was community property. It is difficult to state the exact status of the reasons given in the Carter case. The case on which the Board relied for its Texas law in Hayden v. McMillan, ${ }^{85}$ which was cited for the proposition that where the increase in property is due to "care, labor, or attention" of the members of the community, it is community property. ${ }^{86}$ Hayden v. McMillan, however, was a case construing the Texas statute as to whether rents from the wife's sepa-

81. It can also be argued that Oklahoma changed its statute so as to avoid the Texas confusion, and hence all gains are community property. However, the argument advanced in the text seems the better one.

82. 36 B. T. A. 853 (1937).

83. 122 F. 2 d 721 (C. C. A. 5th 1941), cert. denied, 315 U. S. 811' (1942).

84. O'Connor v. Comm., 110 F. 2d 652 (C. C. A. 5th 1940).

85. 23 S. W. 430 (Tex. 1893).

86. Louisiana has provided by statute that where the separate property of either spouse has been increased during marriage, such increase is community property if it be proved that it resulted from "the common labor, expenses or industry ;", LA. CIV. CoDE, art. 2408 (1945). 
rate property constituted community property. Other Texas cases dealing with increases due to labor of the spouses are cases in which separate property has been invested in an unincorporated business in which one or both the spouses worked. ${ }^{87}$ In these cases the separate property was invested in inventory, the inventory sold and new inventory purchased, so that the particular separate property could never be identified. It is held that since the property has been commingled to such an extent that identification is impossible, the property is community property. ${ }^{88}$

On the basis of the cases decided to date, it is impossible to predict the result under the Pennsylvania law. As a matter of theory, the gain should be allocated between separate property and community property, based on the property contributed and the value of the services rendered..$^{89}$$$
\mathrm{V}
$$ \\ Debts and Obligations}

\section{A. Construction of the Statute}

Section 7 of the Pennsylvania Community Property Act ${ }^{90}$ provides that "that portion of the community property under the manage-

87. Miller v. Marx \& Kempner, 65 Tex. 131 (1885); Smith v. Bailey, 66 Tex. 553, 1 S. W. 627 (1886); Mitchell v. Mitchell, 80 Tex. 101, 15 S. W. 705 (1891); Walker-Smith Co. v. Coker, 176 S. W. 2d 1002 (Tex. Civ. App. 1943).

88. The community, however, is indebted for the value of the separate property contributed. Mitchell v. Mitchell, 80 Tex. 101, 15 S. W. 705 (1891).

89. Allocation between capital and income is made in states where income from property is separate property. Van Vorst, 7 T. C. 826 ; G. C. M. 9825 , X-2 CUM. BuLl. 146 (1931). Similar problems are involved where the separate and community property has been invested in property and the property has been sold at a profit. 3 Mertens, Law of Federal Income Taxation, $\$ \S 19.38,19.40$ (1942).

90. The full text on Sections 7 and 8:

"Section 7. That portion of the community property under the management, control and disposition of the wife, or which stands in her name, shall be liable for debts contracted by the wife and for torts of the wife committed in the course of acquiring, holding or managing such community property, but not otherwise. That portion of the community property which is under the management, control and disposition of the husband shall be liable for debts contracted by the husband and for torts of the husband committed in the course of acquiring, managing, holding or disposing of the community property, but not otherwise. The husband and wife and each of them shall be entitled to the exemptions to which they, or either of them, are entitled under existing laws. All debts created by the husband or wife after marriage, or after the effective date of this act, whichever is later, shall be regarded as community debts unless the contrary be satisfactorily proved.

"Section 8. No creditor shall have recourse to the community property for the payment of debts or liabilities created by either the husband or the wife, except as provided in section 7 of this act: Provided, however, That any creditor may satisfy his claim or demand out of the community property which was under the management, control and disposition of the spouse incurring the indebtedness or liability at the time the debt or liability was contracted or created, and which has been subsequently conveyed or transferred to the other spouse and is under the management, control and disposition of said other spouse without proof that said creditor relied upon said community property in advancing said credit, but without prejudice to the rights of the third party purchasers, encumbrancers or other creditors or grantees; And provided further, That the husband or wife on paying community debts shall, as between themselves, charge the same against community property." 
ment, control, and disposition of the wife, or which stands in her name, shall be liable for debts contracted by the wife and for torts of the wife committed in the course of acquiring, holding, or managing such community property, but not otherwise." As to the husband's debts, the statute provides that "that portion of the community property which is under the management, control, and disposition of the husband shall be liable for debts contracted by the husband and for torts of the husband committed in the course of acquiring, managing, holding, or disposing of the community property, but not otherwise."

The first problem presented by Section 7 is whether all debts contracted by a spouse may be collected out of the property specified, or whether only debts contracted in the course of acquiring, holding, or managing community property may be so collected. Do the words "in the course of acquiring, holding, or managing" apply to debts contracted by the spouse, as well as to torts?

Section 7 of the Pennsylvania Act is identical with Section 7 of the 1945 Oklahoma statute. ${ }^{91}$ Section 7 of the Oklahoma statute is a modification of Section 57 of the 1939 Oklahoma Act, ${ }^{92}$ which in turn was patterned after the Texas statute. ${ }^{93}$ The 1939 Oklahoma Act provided that the separate property of the spouse, community property in the name of the spouse, and community property under the control of the spouse were liable for debts contracted by that spouse and for any liability arising out of that spouse's torts. ${ }^{94}$ It was this provision that led Judge Huxman to dissent in Commissioner v. Harmon when that case was before the Circuit Court of Appeals for the Tenth Circuit. ${ }^{95}$ Judge Huxman pointed out that under the provisions of the Oklahoma statute, the husband could by his acts wipe out the entire interest of the wife, whether those acts were in the interest of the community or not, and hence the wife could not be said to have a vested interest. According to Rayburn L. Foster, Esq., who is one of the draftsmen of the 1945 Oklahoma statute, the seventh section of that

91. Okrahoma Community Property Act, \$7 (1945).

92. OrLahonia Community Property Act, $\$ 57$ (1939), reads as follows:

"Sec. 57. The separate property of the wife and that portion of community property, record title to which is in her name or which is under the management, control and disposition of the wife, shall be subject to debts contracted by the wife or liabilities of the wife arising out of tort, or otherwise, but not to debts or liablities of the husband. The separate property of the husband and that portion of the community property, record title to which is in his name or which is under the management, control and disposition of the husband shall be subject to debts contracted by the husband or liabilities of the husband arising out of tort or otherwise, but not the debts or liabilities of the wife. The husband and the wife, and each of them, shall be entitled to the exemptions to which they, or either of them, are now entitled under the laws existing prior to the enactment of this Act."

93. For a comparison of the Texas and Oklahoma statutes, see page 18 of the respondent's brief in Commissioner of Internal Revenue v. Harmon, 323 U. S. 44 (1944).

94. See note 92 supra.

95. 139 F. 2d 211 (C. C. A. 10th 1943). 
statute was intended to meet Judge Huxman's objection so far as torts are concerned, but not so far as contract debts are concerned. On this point Mr. Foster has written as follows : ${ }^{96}$

"In administering a community estate and paying community debts, the question will naturally arise as to what are community debts. What debts will be paid by the survivor out of the community property and what debts will be left for payment by the administrator of the deceased's estate? In the 1939 Act (Sec. 57, Tit. 32, Okla. Stat. 1941), it was provided that that portion of the community property, record title to which is in the wife's name or which is under her management, control or disposition, shall be subject to the debts of the wife, whether created by her contract or tort. A correlative provision was made with respect. to debts of the husband. In the 1945 Statute, this provision was changed only insofar as it applies to torts. While under the 1939 Act the community property in the hands of the wife and husband, respectively, was liable 'for their individual torts, the 1945 Act provides that it shall be liable only for torts committed in the course of acquiring, holding, or managing the community property; in other words, torts for which a true partnership would be liable. This change was made in order to meet the objection of Judge Huxman of the Circuit Court of Appeals, in his dissenting opinion in the Harmon case, 139 Fed. 2d 211, 216, wherein he concluded that while the decision in that case should be governed by Poe v. Seaborn, 282 U. S. 101, 75 L. Ed. 239, the Oklahoma Act did not meet the requirements of that case because the wife did not have a vested interest in the community estate. Judge Huxman pointed out that under the provisions of Section 57 of Title 32 it was possible for all of the community property in the hands of the husband to be taken and sold for the personal debts of the husband and from this he concluded that the wife's interest was not vested. While it was not thought that this was a valid objection in view of the statutes and decisions of other states whose community property laws were recognized by the Supreme Court, it was sought to obviate this objection insofar as it applied to torts."

Thus the statutory history in Oklahoma indicates that the words following "in the course of" modify only the word "torts" and do not apply to contract debts.

It has been suggested that the punctuation of the first two sentences of Section 7 and the substance of the last sentence of that section indicate that community property is liable only for debts contracted by a spouse in the course of dealing with community property. ${ }^{97}$ So far as

96. Foster, Probating a Conmminity Property Estate, 17 OKLA. B. A. J. 664, 670 (No. 17).

97. Hamilton, Oklahoma Community Property Law as It Affects Operation and Management of Savings and Loan Associations, 16 OkLA. B. A. J. 1077, 1084 (No. 27). 
punctuation is concerned, it plays little, if any, part in the construction of Pennsylvania statutes. ${ }^{97 a}$ So far as the last sentence of the section is concerned, it merely creates a presumption that debts incurred after the start of the community are community debts, and it is difficult to see how this sheds any light on the problem under consideration. A more helpful clue to the meaning of the first two sentences is their syntax. Each sentence says that community property "shall be liable for debts . . . and for torts . .." The repetition of the word "for" is highly significant. It shows that everything following the second "for" is to be linked directly with the word "liable", and is not to apply to the word "debts contracted" since they are between the first "for" and the second "for".

Under the Spanish law community property was liable only for community debts. ${ }^{98}$ This rule has been adopted in Washington ${ }^{89}$ and Arizona. ${ }^{100}$ However, Texas, from which the Pennsylvania statute is derived, has held that separate debts may be collected out of community property. 101

It may be concluded that all debts contracted by a spouse may be collected out of community property under the control of that spouse or standing in that spouse's name, and that the limitations contained in the statute apply only to torts. ${ }^{102}$ In all of the following discussion it is assumed that community property under the management and control of the spouse or which stands in that spouse's name is liable for all debts contracted by that spouse.

\section{B. Debts Existing at the Start of the Community}

In stating what property shall be liable for debts, Section 7 does not specifically limit the word "debts" to those contracted after the start of the community. Does the Section apply to debts" contracted prior to that time? Since Section 7 refers to debts without any reference to the time when they were incurred, it would seem reasonable to conclude that a debt contracted before the start of the community could be collected out of community property which is under the control or which stands in the name of the spouse contracting the debt.

97a. Pa. Stat. Ann. tit. 46, $\$ 553$ (Purdon, 1938).

98. Matienzo, Gloss vir, No. 2, to Nov. Rec. Law 2; Gutierrez, Quaestio cxxix, No. 1, to Nov. Rec. Law 9; Spain: Novisima Recopilacion, Book 10, Title 11, Law 2.

99. Shuey v. Holmes, 20 Wash. 13, 54 Pac. 540 (1898).

100. McFadden v. Watson, 51 Ariz. 110, 74 P. $2 \mathrm{~d} 1181$ (1938); see Forsythe v. Paschal, 34 Ariz. 380, 271 Pac. 865 (1928).

101. Cleveland v. Cole, 65 Tex. 402 (1886).

102. The exemption given by the courts to property held as tenants by the entireties from the claims of creditors of either spouse would seem to be inapplicable because those cases are based on the theory that each tenant holds the entire property. Under the Community. Property Act, each member of the community is "vested with an undivided one-half interest therein." 
Under the Spanish law, ante-nuptial debts could not be collected out of community property. ${ }^{103}$ In Texas ${ }^{104}$ and California, ${ }^{105}$ however, such debts may be collected out of community property. Since the Pennsylvania Act in part is derived from the Texas law, it would seem that its rule would be followed and that such debts would be collectible out of community property.

\section{Definition of Community Debts}

The last sentence of Section 7 of the Act provides that all debts created by the husband or wife after marriage or the effective date of the Act, whichever is later, shall be regarded as community debts unless the contrary be satisfactorily proved. The importance of determining whether a debt created by contract is a community debt or a separate debt arises only on the death of one spouse or on divorce. During the lifetime of both spouses, a debt contracted by one can only be enforced against his or her separate property and the community property under his or her control or standing in his or her name. Under Section 15 of the Act, on death all community debts are to be paid out of community property. Thus a community debt at that time can be paid not only from the community property under the control or standing in the name of the spouse who contracted the debt, but also out of the community property in the control or standing in the name of the other spouse. On divorce, Section 10 provides that the husband and wife shall each be vested with an undivided interest in the community property as tenants in common. The Act contains no express provision, similar to Section 15 relating to death, that on divorce community property is to be used to pay community debts. However, before any community property could be vested in each spouse as tenants in common, all community debts should be paid.

Community debts are debts contracted by either the husband or the wife for the benefit of the community, as for example where the proceeds of the transaction creating the debt are used to produce income for the community, or the debt is incurred to protect community property or is contracted in the ordinary course of business. ${ }^{106}$

103. Spain: Fuero Real, Book 3, Title 20, Law 14.

104. Taylor v. Murphy, 50 Tex. 291 (1878).

105. Van Maren v. Johnson, 15 Cal. 308 (1860).

106. Abbott v. Wetherby, 6 Wash. 507, 33 Pac. 107 (1893) ; Godefroy v. Hupp, 93 Wash. 371, 160 Pac. 1056 (1916) (liability for broker's commission on sale of community property is a community debt) ; Davidson v. Click, 31 N. M. 543, 249 Pac. 100 (1926) (liability for purchase price of property is a community debt). Would husband's liability as surety for a third person be a debt contracted by the husband? Such a debt would probably be held to be based on contract. See Sections 40, 65, 66, 67 and 68 of Act of May 16, 1901, PA. Star. ANn. tit. 56, $\$ \$ 92,156-160$ (Purdon, 1930). Cf. Payne v. Williams, 47 Ariz. 396, 56 P. 2d 186 (1936) (endorsement of a note only for accommodation and not for the benefit of the community is a separate debt) ; Peterson v. Zimmerman, 142 Wash. 385, 253 Pac. 642 (1927) (in a suit on a note 
The last sentence of Section 7 of the Act states a presumption that all debts created are presumed to be community debts unless the contrary be satisfactorily proved. With that presumption, there will be few debts created by contract which are separate debts.

Obligations created by reason of torts committed in connection with specific acts with regard to community property as specified in the statute would be collectible during lifetime out of the community property under the control of or in the name of the spouse committing the tort. Other torts committed by the spouse would be collectible only out of the separate property of the spouse committing the tort and not out of community property. The liability of that separate property would, of course, continue after dissolution of the community for such torts as are then enforceable. However, a question arises as to whether the community property in the hands of the other spouse could be used to satisfy the liability for such torts. Does the presumption that all debts are community debts apply to (1) torts committed in connection with the community property and (2) other torts? The act, in the first part of Section 7, makes a distinction between debts and torts, and then in the last sentence, stating the presumption, merely states that "all debts" shall be regarded as community debts. Does this mean that only contract debts are to come within the presumption, or is it also to apply to liabilities for torts? Ordinarily the word "debts" does not include an unliquidated tort claim. ${ }^{107}$ The distinction in the statute itself and this general rule lead to the conclusion that the presumption does not apply to torts. Therefore, in the case of torts, it is necessary to prove affirmatively that the torts were committed in the course of dealing with community property in order to collect them from the community property.

Torts committed in the course of acquiring, holding, or managing community property would include torts committed in taking possession of the community property, ${ }^{108}$ torts in connection with an attempt to protect community property, ${ }^{109}$ and making secret profits in buying property for a third person. ${ }^{110}$ Likewise, false representations by the husband in conducting a corporate real estate business, of which he is the manager and in which the community holds one-third of the stock,

signed by the husband, the community may show that it was signed as an accommodation, that the community received no benefit from it, and that therefore the community is not liable on it); Sun Life Ass. Co. v. Outler, 172 Wash. 540, 20 P. 2d 1110 (1933) (the husband's endorsement of a note to assist his daughter and son-in-law without aiding the community, is not a community debt).

107. Hollidaysburg Borough v. Snyder, $258 \mathrm{~Pa} .206,101$ Atl. 955 (1917); see Moorehead's Estate, 289 Pa. 542, 137 Atl. 802 (1927).

108. Geissler v. Geissler, 96 Wash. 150, 164 Pac. 746 (1917).

109. McFadden v. Watson, 51 Ariz. 110, 74 P. 2d 1181 (1938).

110. McGregor v. Johnson, 58 Wash. 78, 107 Pac. 1049 (1910). 
give rise to community liability. ${ }^{111}$ However, torts of a spouse acting in his or her capacity as a public official are not community torts. ${ }^{112}$ Nor may community property be subjected to the satisfaction of a judgment for costs rendered in favor of a state in a criminal action against the husband for arson of community property. ${ }^{113}$ A tort liability incurred in the use of a family car for purposes of one spouse without the knowledge or consent of the other spouse is not a community debt. ${ }^{114}$ Moreover, it has been held that the fact that the community is not benefited does not prevent the tort from being a community liability. ${ }^{115}$

Can a debt incurred prior to the start of the community be a community debt? If so, a debt existing at that time, if it qualifies as a community debt, could be enforced not only against the separate property of the spouse contracting the debt and the community property under his or her control or standing in his or her name but also, on death or divorce, out of the community property under the control of or standing in the name of the other spouse. In other words, for a husband's debt, the wife's savings out of income from her separate property or earnings could on the death of the husband or upon divorce be taken by the creditor to pay his debt. It would seem that if the debt in existence at the start of the community was incurred in a transaction out of which income was being produced, or was incurred in protecting property which produced income (assuming that the income or the property was community property), or otherwise benefited the marriage, the debt would be a community debt. If this rule is applied by the courts, a mortgage on the house in which the spouses live, where the husband alone is liable on the bond, would be a community debt and on the death of the husband could be enforced against all community property, whether under his control or that of the wife.

If a husband borrows money for a separate purpose and the wife signs a note making the husband and the wife jointly and severally liable, does the debt become a community debt merely because both husband and wife are liable for the debt? The test as to whether a debt is separate or community does not depend on who is liable for it, but whether it benefits the community. Here by hypothesis the debt

111. Wimmer v. Nicholson, 151 Wash. 199, 275 Pac. 699 (1929).

112. Kies v. Wilkinson, 114 Wash. 89, 194 Pac. 89 (1921); Brotton v. Langert, 1 Wash. 73, 23 Pac. 688 (1890). These decisions are questionable, since acting as public officer produced community income and a tort in connection with such duties should be a community liability.

113. Bergman v. State of Washington, 187 Wash. 622, 60 P. 2d 699 (1936).

114. Bortle v. Osborne, 155 Wash. 585, 285 Pac. 425 (1930). Suppose an accident occurs while husband and wife are using a car for pleasure or wife is using it for shopping or husband is using it for pleasure with knowledge and consent of wife. All torts so committed should be community liabilities.

115. McFadden v. Watson, 51 Ariz. 110, 74 P. 2d 1181 (1938). 
did not benefit the community and hence would not be a community debt but would be the separate debt of the wife and of the husband. As against community creditors the joint liability of the husband and wife does not of itself make the debt a community debt. ${ }^{116}$ Of course, in the example given above the creditor could during the lifetime of both spouses reach all property, whether separate or community, because of the joint and several liability of the spouses; but after the death of either spouse he could not reach community property.

\section{Partnerships}

Will loans to partnerships be affected by the Community Property Act? It often occurs in partnerships that income will be left in the partnership and added to a partner's capital; such income will now be in part the property of the wife and in part the property of the husband. Does this addition of income to capital affect such loans? Under Section 40 of the Uniform Partnership Act, ${ }^{117}$ partnership property is subject to the payment of partnership debts before it can be reached by the separate creditors of any partner. Under that section of the Act, it would appear that a loan to a partnership would have to be paid before the partner's interest in the firm is computed. The reinvestment of community income in the partnership would not affect the payment of such a debt but would affect the persons who were entitled to take what was left of the partner's interest in the partnership after his death.

Since loans to partnerships would always be in connection with a business, such loans would constitute community debts.

\section{E. Use of Community Property to Pay Separate Debts}

The last proviso of Section 8 of the Act states that the husband or wife, on paying community debts, shall, as between themselves, charge the same to community property. Under that section of the Act, if separate property is used by either spouse to pay a community debt, the spouse whose property is so used would be entitled to reimbursement for the amount so used upon dissolution of the community.

Although the use of separate property to pay community debts is expressly covered by the Act, there is no provision covering the use of community property to pay separate debts. Under the construction which has been given to Section 7 of the Act, it is possible for community property to be used to pay a separate debt contracted by a spouse. The Pennsylvania courts will undoubtedly follow the Texas

116. In Katz v. Judd, 108 Wash. 557, 185 Pac. 613 (1919), a husband signed and delivered a note endorsed by his wife, which was a renewal of a similar note given them before marriage. The court held the debt was not a community debt, but the separate debt of each.

117. Pa. Stat. Ann. tit. 59, §102 (Purdon, 1930). 
courts on this point, and in Texas the rule is that a spouse who uses community property to improve separate property must account for that property on a dissolution of the partnership. ${ }^{118}$ Under the law of Texas, if community property is used to improve separate property, a right of reimbursement to the extent of one-half of the amount so used arises in the other spouse. If the property improved is real property, the right of reimbursement does not become an interest in the real estate. The amount to be recovered is to be paid out of separate property, but if such property is insufficient, then the land improved may be sold and the proceeds distributed. Moreover, the amount of recovery under the right of reimbursement is limited to the enhancement of the property by reason of the improvements out of community property at the time of its division. The same rules were applied in the Spanish law. ${ }^{118}$

It would seem that the rules just stated would be applicable under the Pennsylvania Act not only because it in part comes from the Texas statute but also because, as a matter of fairness, the spouse should not be permitted to use community property to improve separate property without accounting for the property so used. Of course, if it could be shown that the other spouse consented to that use, then no accounting would be necessary.

\section{F. Transfers Between Spouses}

Section 8 of the Act permits a creditor to satisfy his claim or demand out of community property which was under the management, control, and disposition of the spouse incurring the indebtedness or liability at the time it was contracted or created and was subsequently conveyed or transferred to the other spouse; and the creditor may do this without first proving that he relied upon the community property in advancing credit. However, the creditor's right in this regard will not be enforced so as to prejudice the rights of third party purchasers, encumbrancers, or other creditors or grantees. Thus a creditor may reach property which was owned by the spouse at the time the debt was created but which has been subsequently transferred to the other spouse. A spouse cannot remove property from the reach of a creditor merely by transferring it to the other member of the community.

118. Dakan v. Dakan, 125 Tex. 305, 83 S. W. $2 d 620$ (1935).

119. Asso and Manuel, Institutes of Civil Law of Spain, Book I, Title VII, $\$ 2$, cap. 5 provides: "That the loss or injury caused to the real estate (hacienda) by" reason of the husband having rented it out at a low rate or price, or having paid annuities (censos) or debts for an illicit cause ought not to prejudice the wife; and therefore in these cases the amount of loss or injury must be deducted from the mass of property and given to the wife before dividing the property." See also MATIENzo, Gloss vir, No. 6, to Nov. Rec. LAw 2 and Gloss Ir, No. 2, to Nov. Rec. LAw 3. 


\section{G. Bankruptcy}

A trustee in bankruptcy ${ }^{120}$ becomes entitled to not only property which the bankrupt can transfer but also to property "which might have been levied upon or sold under judicial process against" the bankrupt or "otherwise seized, impounded or sequestered." 121 For this reason, the trustee in bankruptcy acquires all property which could be disposed of by the bankrupt and which could be reached by the bankrupt's creditors; and in determining whether such a trustee for a spouse can secure any or all of the community property, it is necessary to know whether any or all of such property is subject to the bankrupt spouse's debts under the state law. ${ }^{122}$

Thus, on bankruptcy of one spouse the trustee in bankruptcy may reach the bankrupt's separate property and also that part of the community property under the control of or standing in the bankrupt's name. Community property under the control of the other spouse may not be reached. ${ }^{123}$

\section{H. Application of Community Property Act to Various Loan Trans- actions}

The application of the Community Property Act to various loan transactions may be summarized as follows:

\section{Unsecured Loans}

(a) Debts created by the husband after September 1, 1947. During the life of the borrower such an indebtedness may be collected out of his separate property or out of the community property under his control, disposition or management or which stands in his name. On the death of the borrower if the debt is a community debt, it will then be the obligation of the surviving spouse to pay the debt out of community property (which will include the community property under the control, disposition and management of the husband and also the com-

120. It has been held that the community property must be considered in determining whether one spouse was solvent or insolvent, since the word "property" as used in Section 1(19) of the Federal Bankruptcy Act, as amended, is not limited to property available to pay the bankrupt's debts. See Lasswell v. Stein-Block Co., Inc., 93 F. 2d 322 (C. C. A. 5th 1937). For a general discussion see Moore, The Community Property System and Bankruptcy, 11 WASE. L. REv. $61^{\circ}$ (1936).

121. Section 70 of the Bankruptcy Act, as amended, June 22, 1938, 30 Stat. 565, as amended, 11 U. S. C. $\$ 110$ (1940).

122. Thus, property held as tenants by the entireties is not subject to the debts of each spouse and cannot be reached by the trustee in bankruptcy. Lunnen v. Hunter, 348 Pa. 402, 35 A. 2d 292 (1944); Keirin v. Palumbo, 60 F. 2 d 480 (C. C. A. 3rd 1932).

123. Cases holding that the community may be declared bankrupt would seem to have no application under the Pennsylvania Act. Strong v. Eakin, 11 N. M. 107, 66 Pac. 593 (1901); cf. In re Wallace, 22 F. 2d 171 (E. D. Wash. 1927) ; Smedberg v. Bevilockwaz, 7 Cal. App. 2d 578, 46 P. 2d 820 (1935). 
munity property under the control, disposition and management of the wife), or if that is insufficient, the executor or administrator of the borrower can be required to pay it out of the separate property of the borrower. On the other hand, if the debt is a separate debt, it will not be payable out of the community property but only out of the separate property of the borrower, which of course would include the balance of his one-half interest in the community property after the community debts were paid. Thus lending institutions will probably require both the husband and wife to be made jointly and severally liable. The effect of the husband and wife being jointly and severally liable would probably not be to convert a separate debt into a community debt but at least such liability would permit the lender to proceed against the $50 \%$ interest in the community property which passes to the spouse of the borrower after the payment of community debts.

(b) Debts of the husband existing prior to September 1, 1947. During the life of the borrower such an indebtedness may be collected out of his separate property or out of the community property under his control, disposition or management or which stands in his name. On the death of the borrower such a debt would probably be a separate debt unless it benefits the community through the production of income or the protection of property, in which case what has been said under (a) above would apply. On each renewal by a married person of any indebtedness existing on September 1, 1947, lenders will probably insist that both husband and wife should sign the evidence of indebtedness.

\section{Secured Loans}

(a) Secured by Stocks and Bonds. Stocks and bonds registered in the name of the borrowing husband would be either his separate property or community property under his management, control and disposition, and they could be validly pledged by him as security for a loan without his wife being required to join in the pledge. With respect to such security, the rights of the lender would be the same today as they were prior to September 1,1947 . If the security were insufficient, the borrower's obligation could be enforced, during his lifetime, against his separate property and against community property under his control, disposition or management, or standing in his name. Whether after the death of the borrower the obligation could be enforced as a community debt depends on how the proceeds had been used. What has been stated under 1 (a) and (b) above as to separate and community debts applies here. 
(b) Secured by Accounts Receivable, Warehouse Receipts, Trust Receipts, Bailment Leases, Chattel Mortgages, etc. arising out of or connected with Business Property. The situation with respect to the foregoing types of property is the same as that set forth in the immediately preceding paragraph (a). In addition, such a secured obligation could, whether or not the borrower was living, be enforced against community property because the obligation would be considered a community debt in view of its having been incurred in connection with a business operation which gives rise to community income.

(c) Secured by Warehouse Receipts, Chattel Mortgages, Bailment Leases connected with Non-business Property. The borrower has the right to pledge such property if it is either his individual property or property which is under his control. Such a pledge is in the same category as the pledges referred to in 2 (a) and (b) above. The rights of the bank to proceed against property other than that pledged are the same as those set forth on paragraphs 1 (a) and (b).

\section{Loans to Partnerships}

Since a loan to a partnership made after September 1, 1947 would constitute a community debt, it could be collected during the lifetime of the partner out of the partnership assets, the separate property of the partner, and the community property under the control, disposition and management of the partner. After the partner's death, it could also be collected out of all community property, including that under the control of the wife. Debts existing on September 1, 1947 would constitute community debts since such debts were created for the production of income. The creditor's remedy would be the same as in the case of debts created after September 1, 1947. However, until this question is settled by the courts, it may be that lending institutions will require the obligation of the wife on any renewal of such debts.

\section{Loans to Individual Proprietors}

What has been said under 1 and 2 above with regard to unsecured and secured loans applies to loans to individual proprietors. 